Sir Charles Peers, C.B.E., F.B.A.

THE gold medal of the Royal Society of Antiquaries of London has been awarded to Sir Charles R. Peers in recognition of his services to archæology in Great Britain. This medal, generally accepted as the highest award in archæology in Great Britain, has been awarded on three occasions only, the first recipient being Sir Arthur Evans, who was followed by the Abbé Breuil and then Sir Aurel Stein. Sir Charles Peers, who was educated at Charterhouse and King's College, Cambridge, and is by profession an architect, was appointed inspector of ancient monuments under the Board (now Office) of Works in 1910. His appointment was the result of prolonged agitation by archæologists and others interested in the preservation of antiquities in Great Britain. It marks an epoch in the history of British archæology. The inspectorship had been vacant since the death of General Pitt-Rivers in 1900, while the Ancient Monuments Acts, of which the first was passed in 1882 , had long been virtually a dead letter. In 1913, three years after Sir Charles's appointment, a consolidating and amending Act was passed, which much enlarged the powers of the Commissioners, and he was given the standing and title of chief inspector of ancient monuments.

LARGELY through Sir Charles's activity, notwithstanding the interruption of the Great War, the growth of a public opinion in favour of the preservation of antiquities was fostered and the functions and duties of the Office of Works as the guardian of the nation's interests in its antiquities rendered familiar to a degree which made it possible still further to strengthen the powers of the Department, also recognized in the Town Planning Acts, by the further amending Ancient Monuments Act of 1930. Although Sir Charles retired in 1933, after receiving the honour of knighthood in 1931, he has since then still taken an active part in archæological administration. $\mathrm{He}$ continues to be a member of the Advisory Boards on Ancient Monuments of England, Wales, and Scotland, sits on the Royal Commission on Historical Monuments, as well as on the Standing Committee on Museums, and is an elected trustee of the British and the London Museums. In 1933 he was awarded the Royal Gold Medal of the Royal Institute of British Architects.

\section{Dr. A. E. Dunstan}

THF Council of the Institution of Petroleum Technologists has awarded the Redwood Medal of the Institution to Dr. A. E. Dunstan in recognition of his distinguished services to the science and technology of petroleum. The medal was presented on April 12. Dr. A. E. Dunstan was born at Sheffield in 1878. In 1899 he entered the Royal College of Science, South Kensington. Later on he studied at University College, London, under Ramsay and at East London College under Hewitt. At University College, Dr. Dunstan collaborated with Trouton on investigations into the correlation of physical pro- perties and chemical constitution. He had already published work on viscosity-concentration curves of mixtures. This work was continued at University College and elsewhere, and formed the subject of his thesis in 1910 for the degree of D.Sc. In the meantime, he had communicated numerous papers to the Chemical Society on the problems of viscosity in collaboration with Thole, Wilson, Hunt, Stubbs and others. From 1905 until 1915 Dr. Dunstan was head of the Chemical Department, East Ham Technical College. In 1915 he joined the Anglo-Persian Oil Company. From that time dates the important series of researches on the chemistry and refining of petroleum with which Dr. Dunstan's name is particularly associated. The first important paper relating specifically to the petroleum industry was presented to the Institution in 1916 by Dunstan, Lomax and Thole, and dealt with the pyrogenesis of hydrocarbons. It described the evolution of the process of cracking and of the principles underlying it. A period of intensive research followed on the chemistry of refining processes, during which experimental work was carried out at Abadan and Sunbury. Dr. Dunstan is chief chemist of the Anglo. Iranian Oil Company and a director of National Oil Refineries, Ltd. He was president of the Institution of Petroleum Technologists in 1929-31 and has been honorary editor of the Institution's publications since 1920.

\section{The Magnetic Storm of April 16}

THE magnetic storm which occurred during the Easter week-end appears to have been one of the most violent ever recorded. Particulars of the disturbance have been supplied to NATURE from the Abinger magnetic station of the Royal Observatory, Greenwich, and from Edinburgh. The storm, as recorded at Abinger, considerably exceeded that of January 25 of this year both in range and in intensity. At intervals the photographic traces are difficult to follow on account of the rapidity of change in the earth's magnetic field. Beginning at 5 h. 48 m. U.T. with a sudden sweep of $45^{\prime}$ in declination, the storm almost immediately attained dimensions sufficient to place it among the "great" storms of the past hundred years. Only the salient features are at present available. These may be summarized as follows : The period of most intense activity was from $6 \mathrm{~h}$. to $8 \mathrm{~h}$. U.T. and the storm had virtually ceased by $16 \frac{1}{2} \mathrm{~h}$. The whole range in the vertical component of the field was approximately $500 \gamma-$ not very remarkable except for the short interval of fifteen minutes during which it occurred-between $7 \mathrm{~h} .35 \mathrm{~m}$. and $7 \mathrm{~h} .50 \mathrm{~m}$. The ranges in declination and horizontal intensity are at present subject to reservation. On account of the rapidity of change some doubt exists as to the identification of the auxiliary traces which are brought into the record in lieu of the displaced ordinary trace when large ranges occur. A tentative estimate of $5^{\circ}$ in declination and $2250 \gamma$ in horizontal intensity (that is, nearly one eighth of the whole) has been made by the assistant in charge of the Abinger station. 
Writing on April 19, Dr. A. H. R. Goldie, superintendent (Scotland) Meteorological Office, says : "The storm commenced at $5 \mathrm{~h} .48 \mathrm{~m}$. G.M.T. on April 16, and from the very disturbed traces of the magnetographs at the observatories of Lerwick and Eskdalemuir the following ranges in the magnetic elements on that day have been measured :

Lerwick Horizontal Force, $2980 \gamma\left(1 \gamma=10^{-5}\right.$ c.G.s. units).

Vertical Force, $1386 \gamma$.

Declination, $5^{\circ} 47^{\prime}$, equivalent to $1450 \gamma$ in the component of force perpendicular to the magnetic meridian.

Eskdalemuir Horizontal Force, $1672 \gamma$.

Vertical Force, $1165 \gamma$.

Declination, $6^{\circ} 25^{\prime}$, equivalent to $1850 \gamma$ in the component of force perpendicular to the magnetic meridian."

The storm was probably a sequel to the solar disturbance represented by the large sunspot group which crossed the sun's meridian on April 14.1 U.T. (see Nature, April 16, p. 683).

\section{Aurora Australis on January 22}

A communication from the Commonwealth Solar Observatory, Canberra, published on p. 746, refers to an auroral display observed in Australia on January 22, and the solar eruptions and magnetic storms associated with it and with the brilliant dis. play in Europe on January 25-26. Mr. John Gregory, writing from 11 Bennett Street, Perth, Western Australia, deseribes the aurora of January 22 as seen by him between 8.45 p.m. and 10 p.m. from Busselton, situated on the west coast of Western Australia, a few miles north of latitude $34^{\circ} \mathrm{S}$. Throughout the display, short-wave reception from London was perfect and there was little interference in the broadcast from Perth. Referring to the suggestion that auroræ are sometimes accompanied by audible sounds, Mr. Gregory remarks : "I have witnessed many dazzling displays of Aurora Borealis on the Canadian prairies, in the stillness of remote farming areas, but was never able to detect sounds that could confidently be associated with the lights. The slight mysterious crackling sounds one might hear during a display could be heard on almost any cold night, even when the aurora was entirely quiescent."

\section{Curious Effects of Globular Lightning}

ON December 6 about 4.30 p.m., a ball of lightning was seen falling at an angle of about $30^{\circ}$ to the horizon near Ardglass, Co. Down. It was accompanied by a glare and a loud noise, and on striking the ground there was a burst of flame from the point of impact, followed by a loud explosion. The spot where it fell was examined by Mr. J. A. S. Stendall, of the Belfast Municipal Museum, Miss M. Gaffikin, and Mr. F. Addey, who has kindly supplied all information collected from those who saw the phenomenon. The stem of a hawthorn tree ten inches in diameter had been cut through, and branches had been scattered around, one being thrown 100 yards away from the tree. The bank of a dry ditch had been struck, the point of impact showing clearly from the crushed soil, and fragments of clay were found forty yards away. Excavations were made, as it was believed at first that a meteorite had fallen, but no trace of such could be found at a depth of five feet. At the time of the appearance of the lightning a similar phenomenon was seen at a place six miles away in a north-north-west direction. People described this as accompanied by "a shattering blast which shook the whole countryside". A large crater was found in the mud of a river bank near the scene, but this was quickly covered by the tide and could not be seen when the spot was visited later. The portion covered by the impact could not have been localized to the area of the crater because one person, hearing the explosion, went out and saw sparks jumping off the macadam of the roadway. Mr. Addey suspected a meteorite which had disintegrated, as two balls of globular lightning, separated by six miles, occurring at the same instant, would be rather a rare phenomenon. The fact that a thunderstorm was in progress at the time near Belfast and Lisburn, combined with the fact that there was a partial failure of the electric light in the district, is almost conclusive evidence that the phenomenon was globular lightning.

\section{Tring Museum}

The bequest of the zoological collections at Tring by the late Lord Rothschild is the largest single benefaction both in quantity of specimens and in scientific importance that the British Museum has ever received. The collection may be considered as in two parts, one open to the public and the other reserved for study. In the first section, a general zoological series, are many notable specimens such as the long series of giant tortoises or the superb set of Struthious birds, probably the finest in existence and containing many types. The gorillas and other primates are of equal importance and, in addition, there are specimens of rare or recently extinct animals such as the quagga and fine series of rare marsupials and monotremes. The condition of all these specimens and their taxidermy is of the best. The most important section of the study collections is undoubtedly the enormous series, some two millions, of Lepidoptera. The long series of individual species has yielded, and will continue to yield, much information of scientific value. These Lepidoptera include about six thousand type specimens, a fact which by itself would make this bequest one of outstanding importance to the British Museum. There is likewise an extensive library of zoological, entomological and botanical books comprising about thirty thousand volumes in all. Many of these books are of great rarity. This addition of the Tring Museum will lead, no doubt, to important extensions in the scope of systematic research. Hitherto systematists have too often been hampered by having to work with too short series of specimens. The late Lord Rothschild was alive to this weakness in the founda. (Continued on $p$. 743) 